\title{
Metabolic syndrome and juvenile idiopathic arthritis
}

Clarisse de Almeida Zanette ${ }^{1}$, Sandra Helena Machado², João Carlos Tavares Brenol ${ }^{3}$, Ricardo Machado Xavier ${ }^{4}$

\begin{abstract}
Juvenile idiopathic arthritis (JIA) is the most prevalent chronic arthropathy in childhood and adolescence. The prevalence of metabolic syndrome, as well as obesity, is increasing rapidly in all age groups, including children. Metabolic syndrome is defined as a cluster of risk factors for cardiovascular disease and type 2 diabetes mellitus, including abdominal obesity, insulin resistance, dyslipidemia and hypertension. Besides those components, inflammation has been increasingly considered as a significant component of metabolic syndrome and obesity, and patients with diseases characterized by the presence of chronic inflammation, such as JIA, could represent special risk groups. Glucocorticoids are used routinely in the management of the inflammation of JIA, in high doses and long-term. Long-term use of the glucocorticoids can cause to insulin resistance, hypertension, and obesity, increasing the risk of metabolic syndrome. The aim of this study is to review the literature on the prevalence of different components of metabolic syndrome in patients with JIA. We observed that the data on metabolic syndrome and its components in those patients are very scarce and more studies needed, in view of the potential increased risk of cardiovascular disease.
\end{abstract}

Keywords: juvenile idiopathic arthritis, metabolic syndrome, obesity.

\section{INTRODUCTION}

Juvenile idiopathic arthritis (JIA) is a chronic arthropathy more prevalent in childhood and adolescence. The term describes a heterogeneous group of childhood disorders with chronic inflammation in one or more joints. The onset of JIA is before 16 years of age. Prevalences ranging from 16 to $150 / 100,000$ have been reported in the general population. ${ }^{1}$ The absence of studies on JIA patients in the Brazilian is responsible for the lack of knowledge on the prevalence and incidence of this disorder in our country.

Metabolic syndrome (MetS) is characterized by the presence of a cluster of metabolic abnormalities, especially overweight, abdominal obesity, insulin resistance (IR), dyslipedemia, and hypertension, ${ }^{2-4}$ and it has become increasingly more important due to the association with the development of cardiovascular diseases (CVD) and type 2 diabetes mellitus (T2DM) in adults. ${ }^{3}$
Metabolic syndrome in adults has several definitions, but that of the National Cholesterol Education Program's Adult Treatment Panel III (NCEP/ATP III) ${ }^{4}$, which includes obesity, determined by measuring the abdominal circumference, hypertension, lower levels of high density lipoproteins (HDL-c), elevated triglycerides (TG), and increased fasting glucose among its diagnostic criteria, is used more often. ${ }^{5}$

The prevalence of MetS and obesity has been increasing rapidly in all age groups, including children. ${ }^{2,6}$ Childhood obesity can be classified according to the criteria of the World Health Organization (WHO, 2006). Overweight is defined by the WHO as a body mass index (BMI) (in kilograms divided by the square of the height) between the $85^{\text {th }}$ and $97^{\text {th }}$ percentile, and obesity is defined as a percentile $\geq 97$ for age and gender. ${ }^{7}$ However, a diagnostic consensus for MetS in the pediatric population $^{3}$ does not exist, and the criteria used by different studies have been adapted from adult patterns, using levels dependent on gender and age. ${ }^{6}$

Received on 08/24/2009. Approved on 03/03/2010. We declare no conflict of interest.

This study was conducted at the Rheumatology Department of Hospital das Clínicas de Porto Alegre (HCPA), Medical School (FAMED), Internal Medicine Department, and Universidade Federal do Rio Grande do Sul (UFRGS).

1. Nutritionist, Master's Degree in Medical Sciences from UFRGS

2. Pediatrician, Pediatrics PhD student at UFRGS

3. Professor of the Medical School of UFRGS, Chief of the Internal Medicine Department.

4. Professor of the Medical School of UFRGS, Chief of the Rheumatology Department of HCPA

Correspondence to: Ricardo Machado Xavier. Hospital de Clínicas de Porto Alegre (HCPA). Serviço de Reumatologia. Rua Ramiro Barcellos, 2.350, sala 645

- Bairro Rio Branco. CEP 90035-003. Porto Alegre (RS), Brasil. E-mail: rmaxavier@hcpa.ufrgs.br 
Recently, the International Diabetes Federation (IDF) published its definition of MetS in children and adolescents. The recommendation includes the following criteria: for children between 6 and $<10$ years, obesity is defined as percentile $\geq 90$ and other evaluations can be done in the presence of family history of MetS, T2DM, dyslipidemia, CVD, and hypertension. For children between 10 and $<16$ years, obesity is defined as percentile $\geq 90$, following adult criteria for the levels of TG, HDL-c, blood pressure, and glucose. For adolescents $>16$ years, the IDF recommends the use of the definition of MetS established for adults. ${ }^{8}$

Other studies define MetS in childhood using criteria proposed by the NCEP/ATP III, with the presence of three of the following criteria: ${ }^{5} \mathrm{BMI} \geq 97^{\text {th }}$ percentile, $\mathrm{TG} \geq 110 \mathrm{mg} /$ $\mathrm{dL}$, HDL-c $\leq 40 \mathrm{mg} / \mathrm{dL}$, waist circumference above the $90^{\text {th }}$ percentile (age and gender), glucose levels $>100 \mathrm{mg} / \mathrm{dL}$ and $\geq 95^{\text {th }}$ percentile (age, gender, and height) ${ }^{9,10}$ (Table 1). The determination of insulin resistance (IR) and C-reactive protein (CRP) levels also been reported in studies on MetS and CVD, since the evidence suggests that IR and inflammation could be related with cardiovascular risk. ${ }^{11,12}$

The role of inflammation on MetS has been increasingly demonstrated. ${ }^{13}$ Different pro and anti-inflammatory cytokines, the main regulators of the inflammatory process, induce its effects individually or by interacting with each other. In JIA, studies have demonstrated an imbalance favoring the production of pro-inflammatory cytokines, including interleukin-1 $\beta$ (IL-1 $\beta$ ), interleukin-6 (IL-6), and tumor necrosis factor-alpha (TNF $\alpha$ ), that are important contributors to the perpetuation of the inflammatory response. ${ }^{14}$ Patients with chronic inflammatory diseases have a higher risk of premature CVD..$^{15}$

Glucocorticoids are used routinely in the management of the inflammation of JIA, in high doses and long-term. In the past few years, it has been observed that the chronic use of glucocorticoids could lead to IR, ${ }^{16}$ hypertension, and obesity, all components of the MetS. ${ }^{17}$ Besides, the presence of chronic inflammation in JIA could be added as a cardiovascular risk factor.

Our group studied the nutritional status in 116 JIA patients and the use of glucocorticoids, and found that $23.3 \%$ of the patients were overweight. ${ }^{18}$ However, the prevalence of MetS and obesity were not evaluated in this study.

We carried out a review of the current literature on the investigation of MetS, how this disorder develops in childhood and adolescence, its relationship with long-term use of glucocorticoid and chronic inflammation, and potential consequences in JIA patients. The following descriptors were used in the literature search: juvenile idiopathic arthritis, metabolic syndrome, obesity, glucocorticoids, and inflammation in the MEDLINE and LILACS databases, as well as the 2009 EULAR and ACR congresses.

\section{METABOLIC SYNDROME}

It has been estimated that the prevalence of MetS has been increasing in the pediatric population. However, there is no standardisation of the diagnostic criteria for MS. Epidemiological studies on MetS, using different criteria, have been published recently, but interpretation of the results is hindered due to the lack of consensus on the definition and cut points of its components. ${ }^{3,49}$

According to the definition criteria in children and adolescents, it has been estimated that more than one million American adolescents meet the ATP III criteria for the MetS. ${ }^{2}$ Among published studies, the prevalence of MetS varies from 3 to $42 \%$, with a high prevalence in obese children ${ }^{4,9,19-24}$ (Table 2). According to the Third National Health and Nutrition and

Table 1

Parameters of the Metabolic Syndrome in Children and Adolescents

\begin{tabular}{|c|c|c|c|}
\hline Parâmetros & ATPIII & IDF (10 a 16 anos)* & NHANES III \\
\hline \# of risk factors & $\geq 3$ & $\geq 2$ & Todas \\
\hline Waist circumference & & $\geq$ percentile 90 & $\geq$ percentile 90 \\
\hline Triglycerides & $\geq$ percentile 95 & $\geq 150 \mathrm{mg} / \mathrm{dL}$ & $\geq 110 \mathrm{mg} / \mathrm{dL}$ \\
\hline HDL & $>$ percentile 5 & $<40 \mathrm{mg} / \mathrm{dL}$ & $\leq 40 \mathrm{mg} / \mathrm{dL}$ \\
\hline Glucose & TGC & $\geq 110 \mathrm{mg} / \mathrm{dL}$ & $\geq 110 \mathrm{mg} / \mathrm{dL}$ \\
\hline \multicolumn{4}{|l|}{ Blood pressure } \\
\hline Systolic & > percentile 95 & $>130 \mathrm{mmHg}$ & \\
\hline Diastólica & > percentile 95 & $\geq 85 \mathrm{mmHg}$ & \\
\hline
\end{tabular}

ATPIII: Adult Treatment Panel; IDF: International Diabetes Federation; NHANES III: National Health and Nutrition Examination Survey. IGT: impared glucose tolerance;

* For Children older than 16 years, the IDF adult criteria can be used. 
Table 2

Prevalence of the Metabolic Syndrome (MetS) in Children and Adolescents

\begin{tabular}{|c|c|c|c|c|c|}
\hline Author and year & Study & Population & Age (years) & Definition criteria of MetS & Prevalence of MetS \\
\hline Cook et al., $2003^{9}$ & $\begin{array}{l}\text { Transversal } \\
\text { Data NHANES 1988-1994 }\end{array}$ & 2,430 & 12 to 19 & NHANES III & $4.2 \%$ \\
\hline Ford et al., $2005^{19}$ & $\begin{array}{l}\text { Transversal } \\
\text { Data NHANES 1999-2000 }\end{array}$ & 1,366 & 12 to 17 & NHANES III (TGC) & $5.2 \%$ \\
\hline Ford et al., $2008^{20}$ & $\begin{array}{l}\text { Transversal } \\
\text { Data NHANES 1999-2004 }\end{array}$ & 2,014 & 12 to 17 & IDF & $4.5 \%$ \\
\hline Johnson et al., $2009^{21}$ & $\begin{array}{l}\text { Transversal } \\
\text { Data NHANES 2001-2006 }\end{array}$ & 2,456 & 12 to 19 & NHANES III (glucose $\geq 100$ mg/dL) & $8.6 \%$ \\
\hline Weiss et al., $2004^{22}$ & Cohort & 490 & 4 to 20 & $\begin{array}{l}\text { ATPIII }\left(\text { IGT }>140 \mathrm{mg} / \mathrm{dL}^{*}\right. \\
\text { or HOMA-IR }>15)\end{array}$ & $\begin{array}{c}38.7 \% \text { moderate obesity } \\
\text { and } 49.7 \% \text { severe obesity }\end{array}$ \\
\hline Ferreira et al., $2007^{23}$ & Transversal & 52 & 7 to 10 & $\begin{array}{l}\text { NHANES III /ATPIII (BMI } \geq \\
\text { percentile } 95^{*}, \mathrm{HDL} \leq 38 \mathrm{mg} / \mathrm{dL} \text {, } \\
\text { glucose } \geq 126 \mathrm{mg} / \mathrm{dL} \text { and IR) }\end{array}$ & $17.3 \%$ in obese patients \\
\hline Buff et al., $2007^{24}$ & Transversal & 50 & 2 to 10 & NHANESIII (glucose $\geq 100 \mathrm{mg} / \mathrm{dL}$ ) & $42.3 \%$ obese patients \\
\hline Strufaldi et al., $2008^{4}$ & Transversal & 929 & 6 to 10 & $\begin{array}{l}\left(\mathrm{BMI} \geq \text { percentile } 95^{*}, \mathrm{TG} \geq\right. \\
130 \mathrm{mg} / \mathrm{dL} \text { and } \mathrm{HDL} \leq 40 \mathrm{mg} / \mathrm{dL}, \\
\text { glucose } \geq 100 \mathrm{mg} / \mathrm{dL} \text { or } \mathrm{IR}>3.1 \\
\left.\text { and } \mathrm{BP} \geq \text { percentile } 95^{* *}\right)\end{array}$ & $\begin{array}{l}\text { MetS/ATPIII 9.3\% } \\
\text { MetS/WHO 1.9\% }\end{array}$ \\
\hline
\end{tabular}

NHANES: National Health and Nutrition Examination Survey; IDF: International Diabetes Federation; ATPIII: Adult Treatment Panel; WHO: World Health

Organization; CGT: compromised glucose tolerance; HOMA-IR: Homeostasis Model Assessment - Insulin Resistance; IR: insulin resistance; BMl: body

mass index; HDL: high-density lipoprotein; TG: triglycerides; BP: blood pressure. *age and gender; **age, gender, and height.

Examination Survey (NHANES) III (1988-1994), MetS has a prevalence of $28.7 \%$ in overweight adolescents $\left(\mathrm{BMI} \geq 95^{\text {th }}\right.$ percentile) when compared to at-risk adolescents $\left(\mathrm{BMI} \geq 85^{\text {th }}\right.$ percentile to $\mathrm{BMI}<95^{\text {th }}$ percentile), and $0.1 \%$ in children with normal weight $(\mathrm{BMI}<85)(\mathrm{P}<0.001) .{ }^{9}$

Lee et al. studied the prevalence of MetS in a transversal study with 251 African-American and Caucasian children, using different definitions, and observed that MetS had a prevalence of $18.7 \%$, according to the criteria of Weiss et al. (2004), 21\%, according to the criteria of Cook et al. (2003), $13.4 \%$ using the criteria of Cruz et al. (2004, and $25.1 \%$, according to Ford et al. (2005). ${ }^{25}$

Ferreira et al. investigated the prevalence of MetS and the risk factors for CVD in obese Brazilian children. The authors observed a prevalence of $17.3 \%$, in obese children, and several risk factors for CVD, which showed a strong correlation with IR measured by Homeostasis Model Assessment - Insulin Resistance (HOMA-IR). ${ }^{23}$ In another Brazilian study in São Paulo with school children aged 6 to 10 years, the authors observed that overweight and obesity were associated with MetS, with a prevalence of $25.8 \%$ (ATP III- Adult Treatment Panel - criteria) and 5.2\% (WHO - World Health Organization - criteria), respectively, in overweight children, and $9.3 \%$ and $1.9 \%$, respectively, in children with normal weight. ${ }^{4}$

Studies evaluating the prevalence of metabolic syndrome in JIA were not found.
Due to the difficulty to interpret prevalence studies on MetS because of the use of different criteria, a review of the literature on the prevalence of each specific component of the syndrome would be interesting. Therefore, one would have a better idea on the extension of this health problem in childhood and JIA.

\section{COMPONENTS OF THE METABOLIC SYNDROME}

\section{1) Childhood obesity}

Childhood obesity is a public health concern, and it is directly related to the risk of developing complications of MetS. ${ }^{2}$

The presence of at least one risk factor for CVD (hypertension, dyslipidemia, or hyperinsulinemia) has been observed in $60 \%$ of overweight children and adolescents, while $20 \%$ have two or more risk factors. Besides those risks, obese children are at a higher risk of remaining obese in adult life, and $70 \%$ of them become obese adults. ${ }^{26}$

In a longitudinal study with 191 obese adolescents, Srinivasan et al. observed that $58 \%$ became obese adults, with an incidence of hypertension 8.5 times higher and levels of low-density lipoprotein (LDL-c) and TG 3.1 and 8.3 times greater, respectively, when compared to those that were not overweight in adolescence. ${ }^{27}$

The prevalence of obesity in American children and adolescents is approximately $20 \% .{ }^{28}$ In European countries, 
the prevalence of overweight and obesity among children 7 to 11 years is to $30 \%$ and adolescents between 13 and 17 years the prevalence varies $20-35 \%{ }^{29}$

In Brazil, a study in public and private schools in Bahia were observed a prevalence of $9.3 \%$ of overweight and $4.4 \%$ obesity in children. The prevalence in public schools was $6.5 \%$ and $2.7 \%$, respectively, and in private schools, it was $13.4 \%$ and $7.0 \%$, respectively. ${ }^{30}$ In another study, in São Paulo, the prevalence of obesity, according to three anthropometric criteria - Cole, Must, and WHO, was $8.25 \%, 16.50 \%$, and $11.73 \%$, respectively, in eight public schools. ${ }^{31} \mathrm{~A}$ recent population-based study in Santos, São Paulo, with 10,882 children between 7 to 10 years showed that overweight and obesity had a prevalence of $15.7 \%$ and $18 \%$, respectively. ${ }^{32}$ The study of Strufaldi et al. showed a prevalence of $14.4 \%$ and $13.3 \%$, respectively. ${ }^{4}$

It is known that obesity is a common complication of chronic inflammatory diseases in children and adults, probably reflecting the lack of activity imposed by the disease and treatment with glucocorticoids. ${ }^{33}$ In a German study with 2778 JIA patients, the authors observed a prevalence of $15 \%$ of overweight and $5 \%$ of obesity. The prevalence of overweight was higher in patients on higher doses of corticosteroids $(\mathrm{P}<0.04)$, but this association was not maintained after logistic regression analysis. ${ }^{34}$

In study with 116 JIA patients, was observed a prevalence of overweight in $23.3 \%$ of the patients, and excess adiposity, according to measurements of the tricipital skin-fold, in $12.1 \%$ of the patients. In this population, wedid not identify a significant association between obesity and the use of glucocorticoids (data not shown). ${ }^{18}$

\section{2) Abdominal obesity}

The distribution of body fat, specifically visceral fat, seems to be the link between the adipose tissue and IR, a characteristic of the MetS. ${ }^{35}$

Body fat distribution can be evaluated by a variety of anthropometric procedures. The waist-hip ratio (WHR) has been used in adults. ${ }^{36}$ However, several studies have demonstrated that waist circumference (WC) can be a more reliable tool to determine abdominal obesity, including children. ${ }^{37}$

Studies with children have shown a good correlation between $\mathrm{WC}$ and IR, ${ }^{37}$ and that $\mathrm{WC}$ can identify the risk of a child to develop metabolic and cardiovascular complications. ${ }^{38,39}$

Hirschler et al, investigated the association of WC and MetS in children, and observed prevalences of increased waist circumference (percentile $\geq 90^{\text {th }}$ ) of $0 \%, 28.6 \%$, and $86.5 \%$ in children with normal weight, overweight, and obesity, respectively. The authors concluded that, in children and adolescents, WC is a predictor for MetS and it should be included in clinical practice to identify the risk of cardiovascular diseases in children. ${ }^{38}$

In another Brazilian study, the authors investigated the frequency of MetS in 59 overweight and obese children in the outpatient clinic of a university hospital in São Paulo, observing that WC was increased in $88.1 \%$ of the patients (percentile $\geq 90$ ). ${ }^{24}$

In patients with JIA, we found no studies about abdominal obesity.

\section{3) Insulin resistance}

Insulin resistance and elevated fasting plasma insulin levels, which are very common in obese individuals, seem to be the first sign for the development of T2DM. ${ }^{33,40,41}$ Although the HOMA-IR, one of the methods used more often to estimate IR, is well established for epidemiological studies, a consensus on the use of this tool in clinical practice, with the possibility of anticipating preventive measures, does not exist. ${ }^{42}$

Several studies have suggested that overweight and obesity in children and adolescents are associated with IR and the development of T2DM. In American adolescents, according to NHANES III, T2DM has a prevalence of 4.1 in 1,000 individuals, which is higher than the prevalence of type 1 diabetes mellitus $\left(1.7\right.$ in 1,000). ${ }^{2}$

A study with 55 obese children and 112 obese adolescents demonstrated a reduction in glucose tolerance of $25 \%$ and $21 \%$, respectively, and $4 \%$ of the adolescents also had T2DM. The HOMA-IR was a strong predictor for the reduction in glucose tolerance, confirming that IR in childhood, associated with hyperinsulinemia, is an important risk factor for the reduction of glucose tolerance in children. ${ }^{40}$

Thorsdottir et al. investigated the association between anthropometric measurements and insulin concentration in 262 children and adolescents aged 9 to 15 years. They observed a positive correlation between obesity and insulin levels, but 14 to $20 \%$ of the children had normal weight and elevated insulin levels. These children have risk risk of weight gain when compared to children with normal weight and insulin levels. ${ }^{44}$

In another study, the authors investigated the distribution of insulin and IR, assessed by the HOMA-IR index, in adolescents between 12 and 19 years of age. The HOMA-IR index of girls was higher than that of boys. Obese children (BMI $\geq 95^{\text {th }}$ percentile) had elevated HOMA-IR index when compared to 
children with normal weight (BMI $\geq 85^{\text {th }}$ percentile). Insulin resistance had a prevalence of $52.1 \%{ }^{41}$

We found no studies in the literature evaluating the prevalence of insulin resistance in JIA patients.

\section{4) Dyslipidemia}

Risk factors for CVD, especially the lipid profile, have been investigated in children and adults with rheumatic diseases. ${ }^{45}$

Lipid abnormalities, especially hypertriglyceridemia and low HDL-c, show a strong associated with IR. ${ }^{46}$

The prevalence of dyslipidemia in children and adolescents ranges from 2.9 to $33 \%$ considering total cholesterol levels higher than $200 \mathrm{mg} / \mathrm{dL}^{.77}$

Maffeis et al. observed increased TG levels in $4 \%$ of girls and boys with normal weight, and obesity in $26.2 \%$ and $17.6 \%$, respectively. Zambon et al. observed a prevalence of $15 \%$ of hypertriglyceridemia, $33 \%$ of hypercholesterolemia, and $52 \%$ of low HDL-c in obese children and adolescents. ${ }^{48}$

Urban et al. (2004) investigated serum lipid levels (total cholesterol, LDL-c, HDL-c, and TG), homocysteine, and CRP in 25 children with JIA and 15 healthy children. The authors observed a significant increase in TC, LDL-c, and TG, and reduction in HDL-c in JIA patients. Homocysteine showed a significant correlation with total cholesterol and LDL-c levels. ${ }^{49}$ In another study with JIA patients, the authors evaluated plasma lipoproteins and observed a marked increase in TG and very low-density lipoprotein (VLDL-c) levels and significant reduction in HDL-c levels. Dyslipoproteinemia was observed in patients with higher disease activity, and longer disease duration seemed to increase the risks of atherosclerosis. ${ }^{50}$

\section{5) Hypertension}

Childhood hypertension is associated with obesity and is the most important risk factors for the development of CVD in children. ${ }^{51}$ The association of cardiovascular risk factors, including overweight, IR, and dyslipidemia, is increasingly more common in hypertensive children. ${ }^{52}$

Hypertension in childhood is defined by a systolic or diastolic blood pressure $\geq 95^{\text {th }}$ percentile adjusted for gender, age, and height. ${ }^{53,54}$ The prevalence of hypertension in children and adolescents is not negligible. It varies widly in different reports national and foreign authors, from $1 \%$ to $13 \%$, according to the methodology used..$^{55}$

The presence of hypertension in younger individuals in the United States has increased over the last few years. In a study with 1,740 American students, Jago et al. observed a $24 \%$ prevalence of some type of pressure change: increase in systolic or diastolic pressure, or pre-hypertension, which is elevated when compared to the prevalence of $8 \%$ reported in the NHANES study. ${ }^{57}$

Moura et al. investigated the prevalence of hypertension in Brazilian children. They observed elevated blood pressure in $28.6 \%$ of overweight children, which is significantly different than in children with normal weight $(8.1 \%, \mathrm{P}<0.0001)$ and in children at-high risk for obesity $(12.1 \%, \mathrm{P}=0.016$. Evaluation of the nutritional status by the BMI identified overweight and obesity in $9.3 \%$ and $4.5 \%$, of the children, respectively. ${ }^{58} \mathrm{In}$ another study with Italian children, the authors reported a $1 \%$ prevalence of hypertension in girls and $1.9 \%$ in boys with normal weight, and $52.5 \%$ and $62.7 \%$ in overweight or obese children, respectively. ${ }^{39}$

Due to the absence of studies on hypertension in JIA patients, the prevalence of this disorder in Brazil is not known.

\section{RISK FACTORS FOR METABOLIC SYNDROME}

\section{1) Glucocorticoids}

Glucocorticoids are routinely used as anti-inflammatories and in immunosuppressive therapies. ${ }^{17}$ They can be used systemically by different routes of administration, different doses, and different duration. Glucocorticoids affect several types of cells involved in the inflammatory process. Those drugs also inhibit several pro-inflammatory responses of endothelial cells. ${ }^{59}$

The side effects of corticoids, such as delayed growth, hypertension, T2DM, and obesity, as well as the fact that several of them are also independent risk factors for CVD, are well known. ${ }^{60}$ However, some studies have reported that, due to the anti-inflammatory and anti-proliferative actions, corticotherapy can be cardio-protective. ${ }^{61}$ Wei et al. investigated the association of corticotherapy and cardiovascular risk factors in 68,781 patients treated with glucocorticoids and 82,202 patients not treated with those drugs, hospitalized between 1993 and 1996. The authors observed that the risk of cardiovascular disease, including myocardial infarction and stroke, was higher in patients treated with more than $7.5 \mathrm{mg} /$ day of prednisolone for one to five years. ${ }^{17}$

Our group investigated the impact of the inflammatory activity and use of glucocorticoids in nutritional parameters of patients with JIA. We observed that the cumulative dose of glucocorticoids was not independently associated with short stature or other nutritional parameters. ${ }^{18}$ Longitudinal follow-up for one year showed that the growth rate had a significant association with serum levels of IL-6, but not with 
the cumulative dose of glucocorticoids. Those observations indicate a more predominant role of inflammatory mediators on growth than the chronic exposure to glucocorticoids. The question of whether the same is true for MetS and cardiovascular risk is yet to be determined.

\section{2) Inflammation}

Metabolic syndrome and obesity are considered diseases associated with chronic inflammation. Inflammation is a known component of atherosclerosis, and, recently, some components of MetS have been related to inflammatory markers. ${ }^{63}$

This inflammatory process can be identified by elevated levels of IL-6, TNF $\alpha$, and CRP. Presumably, TNF $\alpha$ and IL-6 work as inflammatory mediators in metabolic disorders, and, in children, they are associated with the degree of adiposity. ${ }^{54}$ Most of those cytokines are directly or indirectly related to processes that contribute for atherosclerosis, hypertension, IR, T2DM, and dyslipidemia, i.e., they could represent a link among adiposity, MetS, and CVD. ${ }^{64}$

C-reactive protein is a marker of inflammatory processes. ${ }^{65}$ Serum levels of CRP are highly sensitive and show a direct relationship with the degree of childhood obesity, and it could be a marker of atherosclerotic progression. ${ }^{54}$

The association of CRP with adipocytes, insulin, dyslipidemia, and hypertension has been shown in healthy pre-pubertal children. ${ }^{13}$ In healthy adolescents, CRP was linked to IR and components of MetS. ${ }^{6}$ Ford et al. investigated the association between MetS and CRP and observed that MetS was associated with elevated concentrations of CRP. Among patients with MetS, $38.4 \%$ had CRP levels $>3 \mathrm{mg} / \mathrm{L}$, and $10.3 \%$ of patients without MetS showed the same levels $(\mathrm{P}<0.007) .{ }^{19}$

Studies showing a clear association between inflammatory activity and the development of MetS in children, but with JIA do not exist.

\section{TREATMENT OF METABOLIC SYNDROME}

Early detection of children and adolescents at risk for MetS is fundamental for fast intervention and risk reduction. Several factors are involved in the genesis of MetS, and, for this reason, several measures should be taken to prevent it.

The prevention and treatment of MetS should be based on lifestyle changes, with emphasis on dietary reeducation and regular physical activities. Dietary intervention is aimed at reducing the ingestion of calories, fats, simple sugars, and sodium and increasing the intake of fiber. Treatment objectives include normalization of blood glucose levels, blood pressure, serum lipid levels, and body weight. ${ }^{53,54}$ Pharmacologic treatment is reserved for patients with a diagnosis of diabetes. ${ }^{54}$

Weight loss has higher impact on MetS. Data in the literature show that a weight loss of $7 \%$ to $10 \%$ is capable of reducing waist circumference, lipid profile, and blood glucose levels. ${ }^{66}$ Treatment of childhood obesity is paramount, and involving the child and adolescent, their families, and their social environment are fundamental to stimulate lifestyle changes. ${ }^{67}$

It is increasingly more clear the need of preventive strategies to reduce the risk of CVD in adult patients with rheumatic diseases. Adult rheumatic diseases, such as rheumatoid arthritis (RA) and systemic lupus erythematosus (SLE), have higher morbidity and mortality rates from early CVD due to the chronic inflammatory overload and reduction in physical activities. Recent data indicate that suppression of inflammation reduces morbidity and mortality rates of CVD in patients with severe RA. Those strategies should be based on understanding the role of inflammation in CVD, as well as management of risk-related lifestyles. Suppression of inflammation by treating RA patients with powerful antirheumatic drugs, as well as TNF inhibitors, can reduce the risk of cardiovascular events. ${ }^{68}$ Other prevention strategies include regular laboratorial exams, to intervene in traditional risk factors, and treatment of dyslipidemia, hypertension and DM, besides stimulating smoking cessation and maintenance of a regular activity program..$^{68,69}$

Currently, studies evaluating the specific treatment of this set of risk factors in children with JIA are not available. Regardless of disease subtype, we suggest that adequate control of the inflammatory response, similar to that used in adult patients, and the use of available treatment resources, such as reducing obesity, increasing physical activities, and measuring and treating different components of MetS, should be done.

\section{CONCLUSION}

The prevalence of metabolic syndrome is increasing among children and adolescents. However, there is no uniformity between the parameters for the diagnosis of the metabolic syndrome in pediatric population, hindering comparison among different populations. The development of metabolic syndrome is associated with the increased risk of T2DM and cardiovascular diseases. Early diagnosis of children and adolescents at risk for metabolic syndrome is crucial for fast intervention and risk reduction. In JIA, there are no sutudies evaluating the prevalence of metabolic syndrome. Current data indicates a higher prevalence of obesity and dyslipidemia. The interactions among components of the metabolic syndrome, inflammation, 
use of glucocorticoids, and other treatments has been actively explored in inflammatory arthropathies and systemic lupus erythematosus in adults, indicating an extremely complex situation. This scenery cannot be extrapolated directly to children and adolescents with JIA, and specific studies in this population are required to identify effective strategies for the prevention and adequate management of metabolic and cardiovascular complications in those patients.

\section{REFERENCIAS}

\section{REFERENCE}

1. Ravelli A, Martini A. Juvenile idiopathic arthritis. Lancet 2007; 369(9563):767-78.

2. Daniels SR, Arnett DK, Eckel RH, Gidding SS, Hayman LL, Kumanyika $\mathrm{S}$ et al. Overweight in children and adolescents: pathophysiology, consequences, prevention, and treatment. Circulation 2005; 111(15):1999-2012.

3. Chen W, Berenson GS. Metabolic syndrome: definition and prevalence in children. J Pediatr 2007; 83(1):1-2.

4. Strufaldi MW, Silva EM, Puccini RF. Metabolic syndrome among prepubertal Brazilian schoolchildren. Diabetes Vasc Dis Res 2008; 5:291-7.

5. Executive Summary of The Third Report of The National Cholesterol Education Program (NCEP) Expert Panel on Detection, Evaluation, And Treatment of High Blood Cholesterol In Adults (Adult Treatment Panel III). JAMA 2001; 285(19):2486-97.

6. Steinberger J, Daniels SR, Eckel RH, Hayman L, Lustig RH, McCrindle $\mathrm{B}$ et al. Progress and challenges in metabolic syndrome in children and adolescents: a scientific statement from the American Heart Association Atherosclerosis, Hypertension, and Obesity in the Young Committee of the Council on Cardiovascular Disease in the Young; Council on Cardiovascular Nursing; and Council on Nutrition, Physical Activity, and Metabolism. Circulation 2009; 119(4):628-47.

7. World Health Organization. WHO Child Growth Standards: length/ height-for-age, weight-forage, weight-for-length, weight-for-height and body mass index-for-age. Methods and development. WHO (nonserial publication): Geneva: WHO; 2006.

8. Zimmet P, Alberti KG, Kaufman F, Tajima N, Silink M, Arslanian S et al. The metabolic syndrome in children and adolescents - an IDF consensus report. Pediatr Diabetes 2007; 8(5):299-306.

9. Cook S, Weitzman M, Auinger P, Nguyen M, Dietz WH. Prevalence of a metabolic syndrome phenotype in adolescents: findings from the third National Health and Nutrition Examination Survey, 1988-1994. Arch Pediatr Adolesc Med 2003; 157(8):821-7.

10. Diagnosis and classification of diabetes mellitus. Diabetes Care 2004; 27(Suppl 1):S5-S10.

11. Raitakari OT, Porkka KV, Ronnemaa T, Knip M, Uhari M, Akerblom HK et al. The role of insulin in clustering of serum lipids and blood pressure in children and adolescents. The Cardiovascular Risk in Young Finns Study. Diabetologia 1995; 38(9):1042-50.

12. Oliveira AC, Oliveira AM, Adan LF, Oliveira NF, Silva AM, Ladeia AM. C-reactive protein and metabolic syndrome in youth: a strong relationship? Obesity 2008; 16(5):1094-8.

13. Cook DG, Mendall MA, Whincup PH, Carey IM, Ballam L, Morris $\mathrm{JE}$ et al. C-reactive protein concentration in children: relationship to adiposity and other cardiovascular risk factors. Atherosclerosis 2000; 149(1):139-50.

14. Woo P. Cytokines in juvenile chronic arthritis. Baillieres Clin Rheumatol 1998; 12(2):219-28.
15. Kaplan MJ. Management of cardiovascular disease risk in chronic inflammatory disorders. Nat Rev Rheumatol 2009; 5(4):208-17.

16. Nicod N, Giusti V, Besse C, Tappy L. Metabolic adaptations to dexamethasone-induced insulin resistance in healthy volunteers. Obes Res 2003; 11(5):625-31.

17. Wei L, MacDonald TM, Walker BR. Taking glucocorticoids by prescription is associated with subsequent cardiovascular disease. Ann Intern Med 2004;141(10):764-70.

18. Souza L, Xavier R, Machado S, Bredemeier M, Brenol J. Impacto da atividade inflamatória e uso de glicocorticoide nas variáveis nutricionais da artrite idiopática juvenil. Rev Bras Reumatol 2005; 45(5):291-300.

19. Ford ES, Ajani UA, Mokdad AH. The metabolic syndrome and concentrations of C-reactive protein among U.S. youth. Diabetes Care 2005; 28(4):878-81.

20. Ford ES, Li C, Zhao G, Pearson WS, Mokdad AH. Prevalence of the metabolic syndrome among U.S. adolescents using the definition from the International Diabetes Federation. Diabetes Care 2008; 31(3):587-9.

21. Johnson WD, Kroon JJ, Greenway FL, Bouchard C, Ryan D, Katzmarzyk PT. Prevalence of risk factors for metabolic syndrome in adolescents: National Health and Nutrition Examination Survey (NHANES), 2001-2006. Arch Pediatr Adolesc Med 2009; 163(4):371-7.

22. Weiss R, Dziura J, Burgert TS, Tamborlane WV, Taksali SE, Yeckel $\mathrm{CW}$ et al. Obesity and the metabolic syndrome in children and adolescents. N Engl J Med2004; 350(23):2362-74.

23. Ferreira AP, Oliveira CE, Franca NM. Metabolic syndrome and risk factors for cardiovascular disease in obese children: the relationship with insulin resistance (HOMA-IR). J Pediatr 2007; 83(1):21-6.

24. Buff CG, Ramos E, Souza FIS, Sarni ROS. Frequência de síndrome metabólica em crianças e adolescentes com sobrepeso e obesidade. Rev Paul Pediatr 2007; 25(3):221-6.

25. Lee S, Bacha F, Gungor N, Arslanian S. Comparison of different definitions of pediatric metabolic syndrome: relation to abdominal adiposity, insulin resistance, adiponectin, and inflammatory biomarkers. J Pediatr 2008; 152(2):177-84.

26. Styne DM. Childhood and adolescent obesity. Prevalence and significance. Pediatr Clin North Am 2001; 48(4):823-54, vii.

27. Srinivasan SR, Bao W, Wattigney WA, Berenson GS. Adolescent overweight is associated with adult overweight and related multiple cardiovascular risk factors: the Bogalusa Heart Study. Metabolism 1996; 45(2):235-40.

28. Imperatore G. Childhood obesity: is it time for action? Nutr Metab Cardiovasc Dis 2006; 16(4):235-8.

29. Lobstein T RN, Leach R. EASO - European Association for the Study of Obesity. International Obesity TaskForce 2005.

30. Oliveira AM, Cerqueira E, Oliveira AC. Prevalência de sobrepeso e obesidade infantil na cidade de Feira de Santana-BA: detecção na família x diagnóstico clínico. J Pediatr 2003; 79(4):325-8.

31. Sotelo YOM, Colugnati FAB, Taddei JAAC. Prevalência de sobrepeso e obesidade entre escolares da rede pública segundo três critérios de diagnóstico antropométrico. Cad Saúde Pública 2004; 20:233-40.

32. Costa RF, Cintra IP, Fisberg M. Prevalência de sobrepeso e obesidade em escolares da cidade de Santos, SP. Arq Bras Endocrinol Metab 2006; 50(1):60-7.

33. Kavey RE, Allada V, Daniels SR, Hayman LL, McCrindle BW, Newburger JW et al. Cardiovascular risk reduction in high-risk pediatric patients: a scientific statement from the American Heart Association Expert Panel on Population and Prevention Science; the Councils on Cardiovascular Disease in the Young, Epidemiology 
and Prevention, Nutrition, Physical Activity and Metabolism, High Blood Pressure Research, Cardiovascular Nursing, and the Kidney in Heart Disease; and the Interdisciplinary Working Group on Quality of Care and Outcomes Research: endorsed by the American Academy of Pediatrics. Circulation 2006; 114(24):2710-38.

34. Niewerth M, Minden K, Foeldvari I, Ganser G, Zink A. Prevalence of being overweight among children and adolescents with juvenile idiopathic arthritis [abstract]. Ann Rheum Dis 2006; 65(suppl 2):449.

35. Ribeiro FFF, Mariosa LS, Ferreira SRG, Zanella MT. Gordura visceral e síndrome metabólica: mais que uma simples associação. Arq Bras Endocrinol Metab 2006; 50(2):230-8.

36. Lerario DDG, Gimeno SG, Franco LJ, M. I, S.R.G. F. Excesso de peso e gordura abdominal para a síndrome metabólica em nipo-brasileiros. Rev Saúde Pública 2002; 36(1):4-11.

37. Molarius A, Seidell JC, Sans S, Tuomilehto J, Kuulasmaa K. Waist and hip circumferences, and waist-hip ratio in 19 populations of the WHO MONICA Project. Int J Obes Relat Metab Disord 1999; 23(2):116-25.

38. Hirschler V, Aranda C, Calcagno Mde L, Maccalini G, Jadzinsky M. Can waist circumference identify children with the metabolic syndrome? Arch Pediatr Adolesc Med 2005; 159(8):740-4.

39. Maffeis C, Banzato C, Talamini G. Waist-to-height ratio, a useful index to identify high metabolic risk in overweight children. J Pediatr 2008; 152(2):207-13.

40. Sinha R, Fisch G, Teague B, Tamborlane WV, Banyas B, Allen K et al. Prevalence of impaired glucose tolerance among children and adolescents with marked obesity. N Engl J Med 2002; 346(11):802-10.

41. Lee JM, Okumura MJ, Davis MM, Herman WH, Gurney JG. Prevalence and determinants of insulin resistance among U.S. adolescents: a population-based study. Diabetes Care 2006; 29(11):2427-32.

42. Wallace TM, Levy JC, Matthews DR. Use and abuse of HOMA modeling. Diabetes Care 2004; 27(6):1487-95.

43. Invitti C, Gilardini L, Pontiggia B, Morabito F, Mazzilli G, Viberti G. Period prevalence of abnormal glucose tolerance and cardiovascular risk factors among obese children attending an obesity centre in Italy. Nutr Metab Cardiovasc Dis 2006; 16(4):256-62.

44. Thorsdottir I, Gunnarsdottir I, Palsson GI, Johannsson E. Anthropometric predictors of serum fasting insulin in 9- and 15-year-old children and adolescents. Nutr Metab Cardiovasc Dis 2006; 16(4):263-71.

45. Ilowite NT, Samuel P, Ginzler E, Jacobson MetS. Dyslipoproteinemia in pediatric systemic lupus erythematosus. Arthritis Rheum 1988; 31(7):859-63.

46. Lewis GF, Carpentier A, Adeli K, Giacca A. Disordered fat storage and mobilization in the pathogenesis of insulin resistance and type 2 diabetes. Endocr Rev 2002; 23(2):201-29.

47. Al-Shehri SN, Saleh ZA, Salama MM, Hassan YM. Prevalence of hyperlipidemia among Saudi school children in Riyadh. Ann Saudi Med 2004; 24(1):6-8.

48. Zambon MP, Antônio MARGM, Mendes RT, Barro AAF. Características clínicas e laboratoriais de crianças e adolescentes obesos. Rev Paul Pediatr 2007; 25(1):27-32.

49. Urban M, Pietrewicz E, Gorska A, Glowinska B. [Lipids and homocysteine level in juvenile idiopathic arthritis]. Pol Merkur Lekarski 2004; 17(99):235-8.

50. Ilowite NT, Samuel P, Beseler L, Jacobson MetS. Dyslipoproteinemia in juvenile rheumatoid arthritis. J Pediatr 1989; 114(5):823-6.

51. Ostchega Y, Carroll M, Prineas RJ, McDowell MA, Louis T, Tilert T. Trends of elevated blood pressure among children and adolescents: data from the National Health and Nutrition Examination Survey1988-2006. Am J Hypertens 2009; 22(1):59-67.
52. Sorof JM, Lai D, Turner J, Poffenbarger T, Portman RJ. Overweight, ethnicity, and the prevalence of hypertension in school-aged children. Pediatrics 2004; 113(3 Pt 1):475-82.

53. Spiotta RT, Luma GB. Evaluating obesity and cardiovascular risk factors in children and adolescents. Am Fam Physician 2008; 78(9):1052-8.

54. Giuliano ICB, Carmelli B, Pellanda L, Ducan B, Mattos S, Fonseca FH. I Diretriz de prevenção da aterosclerose na infância e na adolescência. Arquivos Brasileiros de Cardiologia 2005; 85(Supl VI).

55. Lima EN. Avaliação de fatores de risco associados com elevação da pressão arterial em crianças e adolescentes J Pediatr 2004; 80(1):1-3.

56. Jago R, Harrell JS, McMurray RG, Edelstein S, El Ghormli L, Bassin S. Prevalence of abnormal lipid and blood pressure values among an ethnically diverse population of eighth-grade adolescents and screening implications. Pediatrics 2006; 117(6):2065-73.

57. Monzavi R, Dreimane D, Geffner ME, Braun S, Conrad B, Klier $\mathrm{M}$ et al. Improvement in risk factors for metabolic syndrome and insulin resistance in overweight youth who are treated with lifestyle intervention. Pediatrics 2006; 117(6):e1111-8.

58. Moura AA, Silva MAM, Ferraz MRT, Rivera IR. Prevalência da pressão arterial elevada em escolares e adolescentes de Maceió. J Pediatr 2004; 80(1):35-40.

59. Boumpas DT, Chrousos GP, Wilder RL, Cupps TR, Balow JE. Glucocorticoid therapy for immune-mediated diseases: basic and clinical correlates. Ann Intern Med 1993; 119(12):1198-208.

60. Walker BR, Phillips DI, Noon JP, Panarelli M, Andrew R, Edwards $\mathrm{HV}$ et al. Increased glucocorticoid activity in men with cardiovascular risk factors. Hypertension 1998; 31(4):891-5.

61. Versaci F, Gaspardone A, Tomai F, Ribichini F, Russo P, Proietti I et al. Immunosuppressive Therapy for the Prevention of Restenosis after Coronary Artery Stent Implantation (IMPRESS Study). J Am Coll Cardiol 2002; 40(11):1935-42.

62. Souza LS, Machado SH, Brenol CV, Brenol JC, Xavier RM. Growth velocity and interleukin 6 concentrations in juvenile idiopathic arthritis. J Rheumatol 2008; 35(11):2265-71.

63. Festa A, D'Agostino R, Jr., Howard G, Mykkanen L, Tracy RP, Haffner SM. Chronic subclinical inflammation as part of the insulin resistance syndrome: the Insulin Resistance Atherosclerosis Study (IRAS). Circulation 2000; 102(1):42-7.

64. Lyon CJ, Law RE, Hsueh WA. Minireview: adiposity, inflammation, and atherogenesis. Endocrinology 2003; 144(6):2195-200.

65. III Diretrizes Brasileiras sobre Dislipidemias e Diretriz de Prevenção da Aterosclerose do Departamento de Aterosclerose da Sociedade Brasileira de Cardiologia. Arquivos Brasileiros de Cardiologia 2001; 77(Suppl 3).

66. Fernandez ML. The metabolic syndrome. Nutr Rev 2007; $65(6 \mathrm{Pt}$ 2):S30-4.

67. Lottenberg SA, Glezer A, Turatti LA. Metabolic syndrome: identifying the risk factors. J Pediatr 2007; 83(5 Suppl):S204-8.

68. Turesson C, Jacobsson LT, Matteson EL. Cardiovascular co-morbidity in rheumatic diseases. Vasc Health Risk Manag 2008; 4(3):605-14.

69. Brenol CV, Monticielo OA, Xavier RM, Brenol JCT. Artrite reumatóide e Aterosclerose. Rev Assoc Med Bras 2007; 53(5):465-70. 